\title{
EVALUASI PROGRAM KEWIRAUSAHAAN BENGKEL PADA KEJAR PAKET B DI PKBM TUNAS BANGSA TUGU SEMARANG
}

\author{
AN EVALUATION OF THE WORKSHOP ENTREPRENEURSHIP PROGRAM \\ FOR THE PACKAGE B LEARNING GROUP IN THE COMMUNITY LEARNING ACTIVITY \\ CENTER OF TUNAS BANGSA, TUGU, SEMARANG
}

\author{
Andriyani Pamungkas, Puji Yanti Fauziah \\ PG-TK Mentari Kids, UniversitasNegeri Yogyakarta \\ zalfa.arimbi@yahoo.co.id, pujiyantif@gmail.com
}

\begin{abstract}
Abstrak
Penelitian ini bertujuan untuk mendeskripsikan; (1) Partisipasi dan kebutuhan masyarakat terhadap program, pengetahuan peserta didik tentang bengkel. (2) Motivasi, karakteristik peserta didik dan narasumber, pendanaan, sarana dan prasarana. (3) Aktivitas peserta didik selama pelatihan, strategi pembelajaran, dan hubungan antar pribadi. (4) Dampak yang ditimbulkan. (5) Faktor pendukung dan penghambat pelaksanaan program kewirausahaan bengkel di PKBM Tunas Bangsa Tugu Semarang. Penelitian ini merupakan penelitian evaluatif dengan menggunakan model penelitian CIPP. Pengumpulan data menggunakan metode wawancara, dokumentasi, dan observasi. Hasil penelitian menunjukkan bahwa; Aspek context menunjukkan kesesuaian antara kebutuhan dan partisipasi, pengetahuan peserta didik tentang bengkel. Aspek input menunjukkan motivasi, karakteristik peserta didik dan narasumber, pendanaan, sarana prasarana dalam kategori baik. Aspek process menunjukkan aktivitas peserta didik, strategi pembelajaran, dan hubungan antar pribadi dalam kategori baik. Aspek product menunjukkan kegiatan program terlaksana dengan baik. Faktor pendukung meliputi motivasi yang tinggi dari peserta didik, sarana prasarana. Adapun kendalanya meliputi kekosongan narasumber dan apabila ada barang/peralatan bengkel hilang.
\end{abstract}

Kata Kunci: pelaksanaan program kewirausahaan, keberhasilan program kewirausahaan.

\begin{abstract}
This study aimed to describe; (1) Participation and community needs of the program, learners knowledge of workshop. (2) Motivation, characteristics learners and speaker, facilities and infrastructure. (3) Activities of students during training, learning strategies, and interpersonal relationship.(4) Impact. (5) Factors supporting and inhibiting the implementation of the entrepreneurship program in the CLC of Tunas Bangsa Tugu Semarang. This was an evaluation study employing the CIPP. The data were collected through interviews, documentation, and observations. The results are as follows; The context aspect shows a correspondence between the needs and the participants' participation, and their workshop knowledge. The input aspect shows the participants' motivation and characteristics, the tutors' characteristics, the funding, and the infrastructure facilities which are in the good category. The process aspect shows the participants' activities during the training, the learning strategies, and the interpersonal relationship which are in the good category. The product aspect shows that the activities of the workshop entrepreneurship program can be well implemented. Contributing factors include high motivation, participants' high motivation, and infrastructure facility availability. As for obstacles include vacancy sources and the loss of the workshop equipment.
\end{abstract}

Keywords: implementation of the entrepreneurship program, success of the entrepreneurship program 


\section{PENDAHULUAN}

Dampak krisis yang terjadi di Indonesia sekitar tahun 1997/1998 masih sangat berpengaruh terhadap kehidupan masyarakat, diantaranya adalah masalah pengangguran yang semakin tinggi karena masih banyak masyarakat yang tidak mempunyai keterampilan tertentu, dan banyaknya anakanak yang putus sekolah karena mahalnya biaya sekolah sehingga orang tua tidak mampu menyekolahkan anaknya.

Ini bisa dilihat dari angka kemiskinan di Indonesia sesuai data BPS 2012 sebesar 29,89 juta jiwa atau sebesar $12,36 \%$ dari 237,64 juta penduduk Indonesia hasil sensus penduduk BPS tahun 2010. Sedangkan angka pengangguran terbuka di Indonesia sesuai data BPS bulan Agustus tahun 2012 sebesar 7,24 juta jiwa atau 6,14\% dari jumlah angkatan kerja sebesar 120,41 juta jiwa. Jumlah drop out SMK/SMU/MA ditambah lulusan SLTP, SLTA yang tidak melanjutkan ke pendidikan lebih tinggi sesuai data PDSP Kemdikbud tahun 2011 sebesar 1,7 anak/ tahun.

Negara dikatan makmur apabila jumlah wirausaha minimal mencapai $2 \%$ dari total jumlah penduduk (JUKLAK, 2013, p.1). Untuk mengatasi permasalahan tersebut, pada tahun 1994 pemerintah mencanangkan program pendidikan wajib belajar pendidikan dasar 9 tahun. Melalui program Wajib Belajar 9 tahun, pemerintah menjamin setiap warga negara berumur 7-15 tahun berhak mendapatkan pendidikan dasar di mana pun mereka berada dan apa pun latar belakang sosial-ekonomi mereka.

Sesuai dengan Undang-Undang Sistem Pendidikan Nasional, pendidikan nonformal berfungsi mengembangkan potensi peserta didik dengan penguasaan pengetahuan dan keterampilan fungsional. Sedangkan penyelenggaraan pendidikan nonformal bertujuan untuk membina warga belajar agar memiliki pengetahuan, keterampilan, dan sikap mental yang diperlukan untuk mengembangkan diri, bekerja mencari nafkah atau untuk melanjutkan ketingkat atau jenjang pendidikan yang lebih tinggi. Untuk mencapai tujuan tersebut, pendidikan nonformal perlu memberikan bekal dasar kemampuan, kesanggupan, dan keterampilan kepada peserta didik agar mereka siap menghadapi berbagai kehidupan nyata.

Pembangunan pendidikan melalui PKBM, secara bertahap terus dipacu dan diperluas guna memenuhi kebutuhan masyarakat yang tidak mungkin dapat terlayani melalui jalur formal. Sasaran pendidikan nonformal tidak hanya sekedar berhubungan dengan masyarakat miskin dan bodoh (terbelakang, buta pendidikan dasar, putus sekolah), akan tetapi sasaran pendidikan nonformal terus meluas sesuai dengan perkembangan ilmu pengetahuan dan teknologi serta perkembangan lapangan kerja, perubahan masyarakat terutama berkaitan dengan budaya masyarakat itu sendiri (Kamil, 2009, p.49).

Pada tahun 2012, terdapat 34 kabupaten/kota yang belum memiliki PKBM dari 497 kabupaten/kota. Tahun 2012, telah diluncurkan kegiatan Perluasan Akses PKBM pada 20 kecamatan di 18 kabupaten/kota pada 11 provinsi. Sedangkan layanan Pengembangan PKBM Tematik tahun 2012, telah diberikan pada 20 lembaga PKBM di 11 provinsi yang memiliki unggulan diharapkan dapat menjadi PKBM rujukan. Untuk memenuhi pencapaian PKBM di setiap kabupaten dan adanya PKBM rujukan pada tingkat provinsi tersebut, tahun 2013 Direktur Jendral PAUDNI melalui Pembinaan Pendidikan Masyarakat menyediakan layanan perluasan akses PKBM untuk 8o lembaga yang dialokasikan, untuk kabupaten/kota atau kecamatan yang belum tersedia PKBM, dan Pengembangan PKBM Tematik untuk 25 lembaga yang diprioritaskan pada provinsi lainnya yang belum mendapatkan layanan tersebut (JUKNIS, 2013, p.iii).

Di Jawa Tengah ada 457 PKBM yang tersebar di kabupaten maupun kota. Semarang yang merupakan ibu kota Jawa Tengah memiliki 13 PKBM. Sejalan dengan uraian di atas, salah satu PKBM di Semarang yang memberikan pelatihan/program kewirausahaan kepada peserta didiknya yaitu PKBM Tunas Bangsa Tugu. PKBM Tunas Bangsa memiliki 25 tutor dan 130 warga belajar dari Paket A, Paket B, dan Paket B. Program kewirausahaan yang ada di PKBM Tunas Bangsa Semarang yang diberikan kepada 
warga belajar yaitu (1) menjahit, (2) jasa boga, (3) hantaran, (4) bengkel, (5) jurnalis, dan (6) pertanian, (7) tata kecantikan rambut, (8) SPA, (9) komputer, (10) perhotelan, (11) broadcasting, (12) merangkai bunga, (13) elektronika, (14) houskeeping, (15) jasa boga, (11) bahasa Jepang, (12) tata kecantikan kulit, (13) akuntansi, (14) sekretaris, (15) tata rias penganten, (16) akupuntur, (17) pariwisata, (18) baby sitter, (19) bahasa Inggris, (20) bahasa Arab, (21) jurnalis, dan (22) pertanian.

Dari beberapa program kewirausahaan yang ada di PKBM Tunas Bangsa Tugu tersebut, program kewirausahaan yang paling berkembang dan banyak diminati oleh peserta didik adalah bengkel, karena tempatnya yang strategis tepat di pinggir jalan pantura dimana banyak sekali dilewati kendaraan maka bengkel inipun selalu ramai.

Menurut Undang-Undang No 20 Tahun 2003 tentang Sistem Pendidikan Nasional pasal 1 ayat (10) Satuan pendidikan adalah kelompok layanan pendidikan yang menyelenggarakan pendidikan pada jalur formal, nonformal, dan informal pada setiap jenjang dan jenis pendidikan; ayat (11) Pendidikan formal adalah jalur pendidikan yang terstruktur dan berjenjang yang terdiri atas pendidikan dasar, pendidikan menengah, dan pendidikan tinggi, ayat (12) Pendidikan nonformal adalah jalur pendidikan di luar pendidikan formal yang dapat dilaksanakan secara terstruktur dan berjenjang; ayat (13) Pendidikan informal adalah jalur pendidikan keluarga dan lingkungan.

Dengan tiga macam pendidikan tersebut, maka pendidikan nonformal merupakan salah satu jalur dari penyelenggaraan sistem pendidikan di Indonesia. Sementara itu menurut Archibald Callaway dalam Marzuki (2010, p.99) mendefinisikan pendidikan luar sekolah sebagai suatu bentuk kegiatan belajar yang berlangsung di luar sekolah dan universitas.

Sebagaimana halnya pendidikan formal, pendidikan nonformal juga mempunyai tujuan. Dimana tujuan dari program pendidikan nonformal berhubungan erat dengan kebutuhan belajar yang timbul di dalam masyarakat. Lingkup program pendidikan nonformal terdiri atas pendidikan anak usia dini, keaksaraan, kesetaraan, kecakapan hidup, kepemudaan, pemberdayaan perempuan, pelatihan kerja, dan pendidikan lain.

Santoso S. Hamijoyo dalam Marzuki (2010, p.106) menyatakan bahwa tujuan pendidikan luar sekolah adalah supaya individu dalam hubungannya dengan lingkungan sosial dan alamnya dapat secara bebas dan bertanggung jawab menjadi pendorong ke arah kemajuan, gemar berpartisipasi memperbaiki kehidupan. Memperbaiki kehidupan atau taraf hidup adalah tujuan yang ingin dicapai. Artinya apapun yang dipelajari oleh orang-orang tersebut hendaknya mampu membantu mereka untuk memperbaiki kualitas hidupnya.

Simon dalam Harry Hikmat (2001, p.x) menyatakan bahwa pemberdayaan adalah suatu aktivitas refleksi, suatu proses yang mampu diinisiasikan dan dipertahankan hanya oleh agen atau subjek yang mencari kekuatan atau penentuan diri sendiri (selfdetermination). Sementara proses lainnya hanya dengan memberikan iklim, hubungan, sumber-sumber dan alat-alat prosedural yang melaluinya masyarakat dapat meningkatkan kehidupannya. Pemberdayaan merupakan sistem yang berinteraksi dengan lingkungan sosial dan fisik.

Menurut Hisrich \& Peters (2008, p.8) kewirausahaan (entrepreneur) sebagai:

... entrepreneurship is the process of creating something new with value by devoting the necessary time and effort, assuming the accompanying financial, psychic, and social risk, and receiving the resulting rewards of monetary and personal satisfaction and independence.

Kewirausahaan merupakan sebuah proses menciptakan sesuatu yang baru, yang memiliki nilai dengan mengabadikan waktu dan tenaga, disertai dengan modal (keuangan), psikis, dan berani menanggung resiko, dan menghasilkan keuntungan berbentuk materi, kepuasan tersendiri dan kemandirian.

Menurut Stufflebeam (2003, pp.9-10) mengemukakan: "Evaluation is the process of delinating, obtaining, and providing descriptive and judgemental information about the worth and merit of some object's goals, 
design, implementation, and impacts in order to guide decision making, serve needs for accountability, and promote understanding of the involved phenomena".

Dari definisi tersebut dapat disimpulkan bahwa evaluasi adalah sebagai suatu proses menggambarkan, memperoleh, dan menyediakan informasi yang berguna untuk menilai pengambilan keputusan. Berdasarkan pendapat tersebut, pemberdayaan bukan merupakan upaya pemaksaan kehendak proses yang dipaksakan, kegiatan untuk kepentingan pemrakarsa dari luar, keterlibatan dalam kegiatan tertentu saja, dan makna-makna lain yang tidak sesuai dengan pendelegasian kekuasaan atau kekuatan sesuai potensi yang dimiliki masyarakat.

Model evaluasi ialah model desain evaluasi yang dibuat oleh ahli-ahli atau pakar-pakar evaluasi yang biasanya dinamakan sama dengan pembuatnya atau tahap pembuatannya. Model-model ini dianggap model standar atau dapat dikatakan merek standar dari pembuatannya. Selanjutnya Stufflebeam menggolongkan evaluasi menjadi empat dimensi yaitu: (1) Contect, yaitu situasi atau latar belakang yang mempengaruhi jenis-jenis tujuan dan strategi pendidikan; (2) Input, yaitu sarana/modal/ bahan dan rencana strategi untuk mencapai tujuan; (3) Process, yaitu pelaksanaan strategi dan penggunaan saran/modal/bahan di lapangan; (4) Product, yaitu hasil yang dicapai selama dan akhir pengembangan sistem pendidikan yang bersangkutan.

Evaluasi Model CIPP merupakan salah satu model evaluasi yang terfokus pada pengambilan keputusan. Metode ini mengidentifikasi 4 tipe evaluasi program yang berkaitan dengan 4 tipe keputusan dalam perencanaan program. Evaluasi konteks program menyediakan data mengenai keputusan dalam perencanaan program, evaluasi masukan menyediakan alternatif keputusan tentang rancangan dan sumbersumber program.

Ada beberapa masalah yang menjadi focus kajian dari jurnal ini antara lain: Context Bagaimana partisipasi dan kebutuhan peserta didik terhadap program, letak bengkel, pengetahuan peserta didik tentang bengkel? Input Bagaimana motivasi, karak- teristik peserta didik, karakteristik narasumber, pendanaan, sarana dan prasarana? Process Bagaimana aktivitas peserta didik selama pelatihan, strategi pelatihan dan hubungan antar pribadi?

\section{METODE}

Penelitian ini dikategorikan penelitian evaluasi program (evaluation program research) dengan menggunakan salah satu model evaluasi, yaitu model CIPP yang dikembangkan oleh Stufflebem dan menggunakan pendekatan kualitatif deskripif. Alasan pengambilan model ini karena kedekatannya dengan evaluasi program pendidikan luar sekolah yang sistemik mencakup komponen, proses, dan tujuan program. Pada penelitian ini sasaran yang diambil dalam evaluasi program model CIPP adalah sebagai berikut:

\section{Evaluasi Context}

Sasaran untk Context evaluasi program kewirausahaan bengkel adalah peserta didik dilihat dari partisipasi dan kebutuhan peserta didik, letak bengkel dan pengetahuan peserta didik terhadap program kewirausahaan bengkel.

\section{Evaluasi Input}

Evaluasi Input dengan sasaran peserta didik, narasumber, penyelenggara program dilihat motivasi, karakteristik peserta didik, karakteristik narasumber, pendanaan, sarana dan prasarana.

\section{Evaluasi Process}

Sasaran untuk process evaluasi program kewirausahaan bengkel di PKBM Tunas Bangsa Tugu Semarang yaitu aktivitas peserta didik selama pelatihan, strategi pembelajaran/pelatihan dan hubungan antar pribadi. Indikator-indikator yang akan dievaluasi adalah pembelajaran di kelas meliputi: pendekatan dan metode, pemberian tambahan belajar, pembelajaran praktek, dan waktu pembelajaran/pelatihan.

\section{Evaluasi Product}

Sasaran yang diambil untuk mengevaluasi product yaitu dampak yang ditim- 
bulkan dari penyelenggara program kewirausahaan.

Pada penelitian ini yang menjadi subjek penelitian adalah adalah peserta didik, penyelenggara program kewirausahaan, narasumber, kepala PKBM Tunas Bangsa Semarang.

HASIL

\section{Context}

Kebutuhan dan Partisipasi Peserta Didik terhadap Program

Program kewirausahaan merupakan salah satu cara untuk meningkatkan kualitas kehidupan masyarakat melalui pemberdayaan dengan berbagai program yang memfasilitasi masyarakat untuk melek dalam berbagai bidang. Salah satu program kewirausahaan yang dilaksanakan di PKBM Tunas Bangsa Tugu Semarang yaitu bengkel. Program yang diselenggarakan disesuaikan dengan kebutuhan peserta didik serta melihat peluang di sekitar lokasi penyelenggaraan program.

Letak Bengkel

Pelatihan bengkel yang diadakan karena melihat letak dari PKBM yang dekat dengan jalan raya sehingga cocok untuk mendirikan bengkel. Selain itu sebagai bekal warga belajar untuk mendirikan bengkel sendiri. Hal tersebut diungkapkan oleh pengelola program bahwa: Pelatihan bengkel disini merupakan pelatihan yang diminati para peserta didik karena daerah Mangkang merupakan jalan Pantura. Banyaknya kendaraan yang berlalu lalang membuat bengkel tidak pernah sepi. Karena itu kami akhirnya mendirikan bengkel sendiri. Selain melayani pelanggan yang semakin banyak, bengkel yang kami dirikian ini juga untuk menampung para peserta didik untuk mencari nafkah di sini.

Tujuan pelatihan ini untuk bekal peserta didik mbak. Supaya mereka mempunyai keterampilan. Dengan keterampilan yang diberikan, mereka bisa mendapatkan penghasilan kan? Dan daerah Mangkang tidak pernah sepi kendaraan sehingga pelatihan bengkel yang diberikan kepada peserta didik sangatlah bermanfaat. Baik bagi pengguna jalan maupun peserta didik itu sendiri. Untuk pengguna jalan, apabila kendaraan mereka tiba-tiba rusak di jalan maka mereka bisa memperbaiki kendaraan mereka di sini. Sedangkan untuk peserta didik, mereka bisa memperoleh keterampilan untuk bekal kemandirian mereka.

Berdasarkan hal tersebut, maka tepat kalau diadakan program kewirausahaan bengkel karena letak PKBM yang berada di jalur pantura yang merupakan jalur utama Semarang-Jakarta, dan karena kebutuhan serta keinginan peserta didik yang tinggi untuk mengetahui tentang bengkel.

\section{Input}

Motivasi, Karakteristik Peserta Didik dan Karakteristik Narasumber

Motivasi belajar peserta didik dalam pelatihan sangat antusias dan semangat. Mereka selalu datang tepat waktu, bahkan saat tidak ada pelatihan pun mereka datang ke bengkel untuk membantu-bantu dan belajar kepada pegawai bengkel. Hal ini diungkapkan oleh $\mathrm{AH}$ selaku peserta pelatihan: "Saya sangat senang mengikuti pelatihan bengkel di sini mbak. Dengan ikut pelatihan ini saya jadi semakin tahu bagaimana cara memperbaiki kendaraan. Saya kepengen membuka bengkel sendiri nanti kalau saya sudah mahir". Karena dalam menentukan pelatihan apa yang akan mereka ikuti tidak kami paksa, mereka memilih sendiri apa yang mereka sukai dan apa yang akan mereka pilih. Karena itu mereka sangat senang dan bersemangat mengikuti pelatihan ini".

Peserta didik yang menjadi peserta pelatihan dalam program kewirausahaan bengkel ini atas keinginan mereka sendiri. Apabila setelah mengikuti pelatihan dan mereka tidak cocok dengan pelatihan tersebut, mereka bisa pindah ikut kepelatihan yang lainnya sehingga pelatihan bisa berjalan dengan baik. Selain peserta didik, narasumber memiliki peran yang sangat penting terhadap keberlangsungan program kewirausahaan bengkel. Peranan dan kedudukan yang sangat penting ini menuntut narasumber memiliki keterampilan dan kecakapan yang baik. Oleh karena itu nara- 
sumber harus memiliki kemampuan dalam hal keterampilan tersebut.

Para instruktur/narasumber program kewirausahaan bengkel di PKBM Tunas Bangsa Tugu Semarang telah memiliki kemampuan dibidangnya ini bisa dilihat dari pengalaman mereka. Narasumber diambil dari LPK yang bekerja sama dengan PKBM.

\section{Pendanaan, Sarana dan Prasarana}

Pelatihan bengkel disini memiliki beberapa sumber dana untuk mendukung berjalannya kegiatan. Seperti dikatakan oleh NH selaku kepala PKBM Tunas Bangsa Tugu bahwa: "Awalnya untuk mendanai program kewirausahaan bengkel ini kita memakai dana kita sendiri. Namun sekarang kita mendapat dana dari pusat dengan mengajukan proposal. Dana yang diberikan dari pusat selama ini dapat dikatakan cukup untuk pelaksanaan kegiatan program. Dana yang diperoleh ini sangat membantu untuk menunjang kegiatan program yaitu untuk pembelian alat-alat bengkel yang masih kurang serta biaya operasionalnya".

Selain dana, ketersediaan sarana dan prasarana juga merupakan penunjang supaya program dapat berjalan secara optimal sesuai yang telah direncanakan. Sarana di pelatihan bengkel meliputi obeng, kunci inggris, tang, kunci shok, multitester, kunci busi, palu, tracker, amplas, kunci pas, kunci ring, tanggem, tang potong, test pan, kompresor, cleaner, tenped, oli mesin, kunci palang, drei ketok, linggis, tang betet, jangka sorong. Sarana yang ada pada program pelatihan ini dikatakan lengkap karena mampu memenuhi kebutuhan peserta didik.

Tersedianya sarana pada program membuat aktifitas peserta didik dalam mengikuti kegiatan pelatihan dengan sungguh-sungguh. Peserta didik selalu mengikuti kegiatan sampai selesai dan tidak pernah bolos kecuali kalau memang ada kepentingan yang mendesak. Seperti yang diungkapkan oleh RF bahwa: "Saya tidak pernah membolos mbak, sayang kalau mau membolos. Kalaupun memang tidak bisa datang kepelatihan pasti karena sesuatu yang penting dan memang tidak bisa ditinggalkan”.
Ketersediaan dana dan kelengkapan sarana prasarana dalam pelatihan membuat peserta didik semakin bersemangat dalam kegiatan pelatihan. Dengan tersedianya sarana dan prasarana serta kehadiran peserta didik membuat keberlangsungan program berjalan sesuai dengan apa yang diharapkan.

\section{Process}

\section{Aktivitas Peserta Didik Selama Pelatihan}

Aktivitas peserta didik selama pelatihan sangatlah bagus. Ini bisa dilihat dari kehadiran mereka selama proses pelatihan berlangsung. Seperti yang diungkapkan oleh AD bahwa: "Datang mbak. Mereka kalau tidak datang itu pasti karena suatu hal yang sangat mendesak banget. Soalnya mereka sangat senang mengikuti pelatihan ini makanya mereka jarang tidak masuk".

Hal ini diperkuat oleh pernyataan ZU yaitu: "Bagus. Semangat dan kedisiplinan mereka bagus kok mbak. Saya senang sekali menjadi narasumber di sini. Melihat semangat mereka, sayapun menjadi semangat juga”.

Selain dilihat dari kehadiran peseta didik, penggunaan alat-alat yang tersedia juga merupakan salah satu keberlangsungan dalam pembelajaran. Seperti yang diungkapkan oleh AD: Hal ini juga sesuai dengan hasil wawancara dengan ZU selaku narasumber pelatihan bengkel bahwa: "Digunakan sebaik mungkin supaya tidak menghambat proses pelatihan".

Interaksi antara peserta didik dengan narasumber harus baik pula supaya terjalin komunikasi sehingga tidak ada kesenjangan antara peserta didik dengan narasumber. Dengan komunikasi yang baik maka suasana belajar mengajar lebih nyaman, tidak ada ketegangan. Suasana yang nyaman akan membuat peserta didik tidak akan bosan dan mereka juga bisa lebih santai tapi serius dalam belajar.

Aktivitas dalam pelatihan didukung oleh kehadiran peserta didik, alat-alat pelatihan yang memadai serta terjalinnya komunikasi yang baik akan menciptakan suasana belajar mengajar yang nyaman sehingga peserta didik tidak akan merasa bosan. 
Metode Pelatihan dan Hubungan Antar Pribadi

Pelatihan merupakan salah satu kegiatan untuk mengajari peserta didik supaya lebih mandiri. Belajar mandiri merupakan kegiatan pembelajaran yang dirancang dan dilaksanakan oleh peserta didik dengan bimbingan pendidik atau disesuaikan dengan kebutuhan, kesempatan, penyelesaian dan ketuntasan yang diatur oleh perserta didik.

Pertama, metode pelatihan kewirausahaan bengkel di PKBM Tunas Bangsa Semarang Pembelajaran kewirausahaan bengkel ini dilakukan selama 200 jam pelajaran. Dengan 4 orang narasumber teknis dan dilakukan dua tahap pembelajaran. Pertama dengan pemberian teori kepada peserta didik dan yang kedua dengan praktik langsung ke lapangan/magang. Tahap pertama dilakukan selama 3 hari. Ini diberikan untuk mengenalkan mereka dasar-dasar bengkel, alat-alat serta bagaimana cara menggunakan alat-alat tersebut. Setelah 3 hari diberikan teori, peserta didik langsung praktik lapangan/magang selama 3 bulan.

Kedua, pelaksanaan pembelajaran kewirausahaan bengkel di PKBM Tunas Bangsa Semarang Pembelajaran pada pelatihan bengkel diberikan materi dan pemagangan. Selama 3 hari klasikal atau pemberian materi. Selanjutnya dilakukan magang selama 3 bulan. Hal ini dilakukan supaya peserta didik bisa mengenal dan mengerti dasardasar apa yang harus dilakukan dan untuk memperkenalkan mereka akan alat-alat yang digunakan dalam pelatihan.

Ketiga, pelaksanaan monitoring dan evaluasi pada pembelajaran kewirausahaan bengkel di PKBM Tunas Bangsa Semarang Monitoring dan evaluasi dilakukan setelah praktik lapangan berlangsung selama 2 bulan. Monitoring dan evaluasi ini dilakukan untuk mengetahui bagaimana proses pelatihan itu berlangsung, dan supaya bisa mengetahui apa saja yang kurang dan perlu diperbaiki.
Product (Evaluasi Hasil Pelaksanaan Program Kewirausahaan Bengkel)

Penyelenggaraan program kewirausahaan digagas dan dikembangkan oleh Direktorat Pembinaan Pendidikan Masyarakat, Direktorat Jendral PAUDNI, Kementerian Pendidikan dan Kebudayaan yaitu pembelajaran kewirausahaan, rintisan inkubator wirausaha atau bisnis, dan pengembangan sentra kewirausahaan. Keberhasilan program kewirausahaan bengkel yang dilihat melalui evaluasi pelaksanaan program yang diukur dari empat aspek dan tahapan yang digunakan dalam pelaksanaan program tersebut mendapatkan hasil yang baik. Keberhasilan program yang menggunakan empat aspek yang diambil dari model implemesntasi Grindle,Edwar III, Van Meter dan Van Horn, dan Sabatir (Wahap, 1992, p.22).

Sikap pelaksana yang mendukung program akan menumbuhkan kreatifitas agar implementasi lebih efektif, sumber daya yang memadai untuk setiap kegiatan implmentasi program, sumber daya tersebut dapat berupa sumber daya manusia sebagai pelaksana dan sumber dana untuk mendukung kelancaran program, komunikasi yang baik merupakan penghubung antar pelaksana atau penyampaian pesan dari pemerintah ke publik, daya dukung masyarakat adalah tingkat partisipasi masyarakat penerima dalam melaksanakan program."

Dalam pelaksanaan program harus didukung dengan sikap pelaksana yang mendukung program yang dilaksanakan agar memperoleh hasil yang baik, sebuah program juga harus memiliki sumber daya baik manusianya maupun dana yang diberikan untuk kelancaran program,komunikasi antar pelaksana dan penerima program merupakan alat penghubung, dan daya dukung dari masyarakat.

Dari aspek-aspek tersebut akan mengetahui hasil pelaksanaan program kewirausahaan bengkel agar dapat menolong dirinya sendiri melalui keterampilan yang didapat dari pelatihan yang diberikan.

Dalam pelaksanaan program kewirausahaan bengkel, tidak hanya teori yang diberikan kepada peserta didik tetapi mere- 
ka juga diberikan praktik lapangan. Pemberian tanggung jawab kepada peserta didik dilakukan saat praktik lapangan. Dengan tanggung jawab yang diberikan kepada peserta didik, mereka akan mampu bekerja sama baik dengan kelompoknya maupun dengan kelompok lain. Dengan praktik lapangan ini tentunya pengalaman mereka menjadi bertambah, dan mereka menjadi lebih mandiri, serta mempunyai ide kreatif dan inisiatif untuk mengambil keputusan.

\section{Faktor Pendukung dan Penghambat Pelaksanaan Program Kewirausahaan Bengkel di PKBM Tunas Bangsa Tugu Semarang}

\section{Faktor Pendukung}

Keberhasilan suatu program tidak bisa terlepas dari adanya faktor pendukung yang menjadi kekuatan dalam proses pelaksanaannya. Berjalannya program kewirausahaan bengkel di PKBM Tunas Bangsa Tugu sesuai dengan kebutuhan para peserta didik, dikarenakan adanya beberapa faktor pendukung. Faktor tersebut yaitu: Pertama, dana dari pusat. Adanya dana dari pusat sehingga perlengkapan untuk menunjang proses pelatihan dapat terpenuhi.

Kedua, tempat yang strategis. Letak bengkel yang berada di jalur pantura Semarang-Jakarta ini membuat bengkel tidak pernah sepi. Hal ini tentunya menguntungkan bagi peserta didik, karena mereka selalu bisa mempraktekkan apa yang telah mereka pelajari.

Ketiga, dukungan dari peserta didik. Dukungan dari peserta didik dan/warga masyarakat sekitar dalam program kewirausahaan sangatlah penting, karena tanpa dukungan mereka maka program ini tidak akan berlangsung. Seperti yang diungkapkan oleh HD: "Adanya bantuan dana dari pusat mbak. Keterlibatan dari peserta didik maupun warga masyarakat sekitar sangat membantu keberhasilan program ini karena mereka bersungguh-sungguh dalam mengerjakan sesuatunya, sehingga hasil yang diperolehpun baik dan tidak sedikit dari pengguna jalan mempercayakan dan kembali lagi ke bengkel kita apabila kendaraan mereka rusak".

\section{Faktor Penghambat}

Banyak hal yang bisa menjadi penghambat dalam pelaksanaan program. Begitu juga yang terjadi pada program kewirausahaan bengkel di PKBM Tunas Bangsa Tugu, tidak semuanya berjalan sesuai dengan apa yang telah direncanakan. Pertama, kurangnya fasilitator. Hal ini menyebabkan fasilitator para fasilitator merangkap untuk menjadi pengajar dan menjadi pelatihan dalam program kewirausahaan.

Kedua, peserta didik benar benar belum mengetahui tentang perbengkelan. Mereka yang ikut kebanyakan masing belum begitu mengerti bagaimana cara memperbaiki kendaraan, bahkan banyak juga diantara mereka yang belum mengenal nama alat-alat yang digunakan. Ini membuat fasilitator harus memulai benar-benar dari awal.

\section{PEMBAHASAN}

\section{Context (Partisipasi dan Kebutuhan Masyarakat terhadap Program, Letak Bengkel Apakah Strategis, Pengetahuan Peserta Didik tentang Bengkel)}

Pendidikan nonformal mengutamakan program yang berkaitan dengan upaya pemenuhan kebutuhan yang dirasakan dan dinyatakan oleh masyarakat pada dasarnya berorientasi pada pembinaan dan pengembangan kewirausahaan.

Kewirausahaan amat penting bagi proses pemberdayaan masyarakat di bidang ekonomi yang terkait dengan bidang sosial, budaya, politik. Dengan adanya program kewirausahaan, masyarakat bisa meningkatkan kualitas kehidupan masyarakat melalui pemberdayaan dengan berbagai program yang memfasilitasi masyarakat untuk melek dalam berbagai bidang kehidupan.

Berdasarkan Acuan Kurikulum Pendidikan Kesetaraan (Depdiknas, 2004, pp.5-6), program ini bertujuan: (1) Membentuk warga negara yang beriman, bertaqwa, berkarakter dan bermartabat; (2) Memberikan pembelajaran bermakna dan produktif dengan standar yang memadai; (3) Memberikan kecakapan hidup yang berorientasi mata pencaharian, kewirausahaan, kejuruan dan pekerjaan, dan (4) Memberikan pembe- 
kalan untuk melanjutkan ke perguruan tinggi dan hidup di masyarakat.

Program Paket B berfungsi untuk mengembangkan pengetahuan, keterampilan, sikap dan nilai yang setara dengan SMP. Selain itu acuan PKBM dalam proses peningkatan kemandirian peserta didik menurut Kindervatter (Kamil, 2009, p.128) ada delapan karakteristik, yaitu: (a) membentuk kelompok belajar menjadi kelompok kecil, (b) melatih agen sebagai fasilitator, (c) melatih fasilitator sebagai pemimpin partisipatif, (d) secara berangsur dilakukan pengalihan tanggung jawab kegiatan agen kepada peserta didik, (e) interaksi dijalin dalam kerangka hubungan yang non-hierarkial dan demokratis, (f) kegiatan merupakan integrasi antara aksi dan refleksi, (g) tumbuhnya kesadaran diri (self-reliance), (h) meningkatkan kemandirian bidang sosial, ekonomi dan/atau politik.

Salah satu program untuk meningkatkan keterampilan peserta didik di PKBM Tunas Bangsa Tugu yaitu menyelenggarakan program kewirausahaan bengkel. Penyelenggaraan program kewirausahaan tersebut dirancang untuk memberikan bekal keterampilan, pengetahuan, percaya diri, tekun, mandiri, berorientasi pada tindakan, belajar sambil bekerja, kerja keras, dan kreatif untuk memperbaiki masa depannya.

Konteks penyelenggaraan program kewirausahaan tersebut terkait dengan partisipasi peserta didik terhadap kegiatan kewirausahaan bengkel cukup baik. Hal ini dikarenakan peserta didik memilih sendiri kegiatan apa yang mereka sukai dan merupakan kebutuhan belajarnya. Dalam proses pembelajaran peserta didik memiliki kesungguhan dalam belajar. Kurangnya keterampilan pada peserta didik membuat sikap keingintahuan mereka menjadi tinggi. Sikap keingin tahuan ini menjadikan peserta didik selalu hadir pada saat pelatihan diadakan.

Program kewirausahaan yang diberikan kepada peserta didik menjadikan mereka merubah sikap maupun kebiasaan mereka. Peserta didik memiliki sikap kewirausahaan yang sesuai dengan yang diharapkan yaitu mereka lebih percaya diri dalam bekerja dan berusaha, mulai memberanikan diri memperbaiki kendaraan bermotor yang rusak sendiri tanpa didampingi fasilitator, dan yang pasti mereka lebih mandiri dibanding sebelum mengikuti pelatihan. Motivasi untuk dapat meningkatkan kualitas hidup dan wirausaha yang mandiri ini juga bisa dilihat dari kebiasaan peserta didik yang sudah mulai berubah, beberapa peserta didik yang tidak mempunyai kegiatan/pengangguran kini mulai memiliki aktivitas.

\section{Input (Motivasi, Karakteristik Peserta Didik dan Narasumber, Pendanaan, Sarana dan Prasarana)}

Penyelenggaraan suatu program akan berjalan dengan baik apabila adanya partisipasi dan motivasi yang baik pula dari peserta didik. Motivasi pada peserta didik tersebut dapat meningkatkan keinginan tahuan mereka terhadap suatu hal yang baru sehingga dapat mempengaruhi pula kegiatan belajar mereka.

Ada beberapa pendekatan belajar yang ada pada PKBM Tunas Bangsa yaitu dengan cara: (a) belajar sendiri dengan memanfaatkan pengalamannya dari pekerjaan yang dilakukan sehingga memperoleh pengetahuan dan keterampilan; (b) saling belajar antara warga belajar yang sudah mengetahui hal tertentu dengan warga belajar yang belum mengetahuinya; (c) belajar bersama dengan tutor untuk memperoleh pengetahuan dan keterampilan; (d) kursus bidang pengetahuan dan keterampilan di bawah bimbingan sumber belajar, dan (e) magang dengan cara ikut belajar, bekerja, berusaha bidang pengetahuan dan keterampilan kepada seseorang yang sudah mahir keterampilannya (Komar, 2006, p.237).

Pada penyelenggaraan program kewirausahaan bengkel di PKBM Tunas Bangsa Tugu Semarang, berdasarkan hasil wawancara menunjukkan proses penyelenggaraan dapat dikatakan baik. Hasil observasi juga menunjukkan bahwa fasilitas sarana-prasarana dan keadaan lingkungan dikatakan baik karena dapat mendukung dan memenuhi kebutuhan peserta didik.

Motivasi peserta didik pun dapat disimpulkan dalam mengikuti kegiatan belajar mengajar maupun pelatihan cukup tinggi. Motivasi peserta didik untuk menyumbangkan ide-ide kreatif dan membangun meru- 
pakan faktor yang dapat membantu keberhasilan program. Indikator ini memberikan bukti bahwa inovasi akan muncul apabila peserta didik diberikan keleluasaan untuk ikut menyumbangkan ide-ide mereka untuk mengembangkan program yang ada.

Sarana dan prasarana yang mendukung dalam pelatihan bengkel di PKBM Tunas Bangsa Tugu Semarang tentunya sangat bermanfaat. Sehingga dalam kegiatan pelatihan baik dalam pemberian teori maupun praktik lapangan pastinya akan sesuai dengan yang diharapkan, baik dari pihak pengelola maupun peserta didik.

Pendidikan peserta didik yang berbeda-beda tidak menjadi hambatan dalam pelaksanaan program kewirausahaan tersebut. Beberapa dari mereka bahkan belum memiliki pengetahuan sama sekali tentang bengkel. Hal ini tentunya membuat narasumber atau fasilitator lebih optimal dalam memberikan pembelajaran.

\section{Process (Aktivitas Peserta Didik Selama Pelatihan, Metode Pelatihan dan Hubungan Antar Pribadi)}

Banyak pilihan yang dapat digunakan oleh fasilitator dalam memproses interaksi belajar untuk mencapai tujuan tertentu. Dalam pemilihan metode yang akan dipergunakan, diperlukan beberapa faktor yang harus dipertimbangkan, yaitu: tujuan pembelajaran, sifat materi pembelajaran, peserta, fasilitator, waktu, dan daya dukung sarana prasarana. Dan tentunya peserta didik ikut dilibatkan dalam pemilihan metode yang akan digunakan dalam pembelajaran.

Metode pembelajaran yang dapat diterapkan dalam pembelajaran kewirausahaan yang subjeknya orang dewasa yaitu: (1) metode ceramah, (2) metode kelompok (3) metode demonstrasi (4) tutorial, (5) tanya jawab, dan (6) belajar sambil melakukan (Suryono \& Sumarno, 2012, p.131).

Kondisi ini juga terjadi pada pelatihan yang diadakan di PKBM Tunas Bangsa Tugu yang dirancang dan dilaksanakan oleh peserta didik dengan bimbingan pendidik atau disesuaikan dengan kebutuhan mereka ini salah satunya untuk melatih kemandirian. Dengan begitu mereka ketergantungan terhadap orang lain tidak lagi ada pada diri peserta didik. Mereka bisa mengambil keputusan atau berindak sesuai dengan keinginan dan kebutuhan mereka sendiri, termasuk mencukupi kebutuhan hidupnya.

Strategi pembelajaran kewirausahaan bengkel yang diterapkan dalam proses pembelajaran yaitu dilakukan dalam dua tahap yaitu pemberian teori dan praktik langsung ke lapangan. Pada tahap pemberian teori dilakukan selama 3 hari. Tahap ini dilakukan karena beberapa diantara peserta didik yang mengikuti pelatihan belum paham dan mengerti benar tentang bengkel. Sehingga pemberian teori kepada mereka sangatlah penting supaya mereka mengerti apa saja dan yang harus dilakukan sebelum terjun langsung ke lapangan. Setelah pemberian teori selesai dan peserta didik mengerti dasar-dasar tentang bengkel mereka dimagangkan selama tiga bulan di bengkel untuk menerapkan apa yang telah mereka pelajari.

Strategi pembelajaran seperti ini sangat diterima oleh peserta didik, karena apabila mereka mengerti dan mengenal tantang bengkel tentunya mereka tidak akan kesulitan dalam praktik langsung ke lapangan. Dengan strategi seperti ini, hubungan antara peserta didik dengan narasumber atau fasilitator menjadi dekat. Kedekatan yang terjalin ini membuat mereka merasa nyaman dan senang mengikuti program kewirausahaan.

Pelaksanaan pembelajaran kewirausahaan bengkel di PKBM Tunas Bangsa Semarang diberikan secara teori dan praktik. Selama 3 hari klasikal atau pemberian materi. Selanjutnya dilakukan magang selama 3 bulan. Dengan begini peserta didik tidak akan mengalami kesulitan di lapangan karena mereka tentunya sudah mempunyai bekal dasar-dasar yang akan mereka lakukan.

Metode yang digunakan dalam pelatihan kewirausahaan sendiri menggunakan beberapa metode. Di mana metode tersebut disesuaikan dengan kebutuhan saat pelatihan berlangsung. PKBM Tunas Bangsa Tugu pun menggunakan metode tersebut, yaitu: (1) metode ceramah, (2) metode kelompok (3) metode demonstrasi (4) tutorial, (5) tanya jawab, dan (6) belajar sambil melaku- 
kan, dimana masing-masing metode digunakan dalam pemberian teori maupun praktik lapangan disesuaikan dengan kebutuhan peserta didik.

Pelaksanaan monitoring dan evaluasi dilakukan setelah praktik lapangan berlangsung selama 2 bulan. Monitoring dan evaluasi ini dilakukan untuk mengetahui bagaimana proses pelatihan itu berlangsung, dan supaya bisa mengetahui apa saja yang kurang dan perlu diperbaiki. Selain dari aktivitas dan metode yang digunakan, hubungan yang terjadi baik antar peserta didik maupun peserta didik dengan narasumber tentunya juga menjadi faktor penentu keberlangsungan program. Hubungan komunikasi yang melibatkan emosi dan mental peserta didik harus terjalin dengan baik pula. Begitu juga dengan yang terjadi pada program kewirausahaan bengkel di PKBM Tunas Bangsa Tugu berjalan dengan baik. Adanya komunikasi antara peserta didik dengan narasumber ini membuat suasana belajar mengajar menjadi lebih nyaman.

\section{Product (Evaluasi Hasil Pelaksanaan Program Kewirausahaan Bengkel)}

Pendidikan nonformal diselenggarakan di lingkungan masyarakat dan lembagalembaga, untuk melayani kebutuhan belajar para peserta didik sehingga warga masyarakat mengetahui bagaimana cara belajar yang cocok dengan kebutuhan dan kebiasaan mereka, terampil memilih dan melakukan kegiatan belajar, serta dapat berinteraksi positif dengan sumber belajar dan lingkungannya.

Menurut Kamil (2009, p.86) ada tiga tujuan penting dalam rangka pendirian dan pengembangan PKBM yaitu: (a) Memberdayakan masyarakat agar mampu mandiri (berdaya), b) meningkatkan kualitas hidup masyarakat baik dari segi sosial maupun ekonomi, dan (c) meningkatkan kepekaan terhadap masalah-masalah yang terjadi di lingkungannya sehingga mampu memecahkan permasalahan tersebut.

Sesuai dengan pengertian tersebut, program kewirausahaan yang di adakan di PKBM Tunas Bangsa Tugu Semarang saat pemilihan program apa yang akan diselenggarakan di sesuaikan dulu oleh penyeleng- gara. Mereka melihat potensi apa yang ada di sekitar, serta apa saja kebutuhan peserta didik. Dengan penyesuaian ini, diharapkan program yang terselenggara akan bermanfaat bagi peserta didik maupun masyarakat sekitar.

Dalam pelaksanaan pelatihan program kewirausahaan bengkel di PKBM Tunas Bangsa Tugu sejalan dengan pernyataan di atas, yaitu melalui beberapa tahap untuk mendapatkan hasil yang maksimal. Teori yang diberikan kepada peserta didik tentulah sangat membantu mereka. Selain teori yang diberikan, tentunya praktik lapangan sangatlah penting untuk mereka. Pemberian tanggung jawab kepada peserta didik dilakukan saat praktik lapangan. Dengan tanggung jawab yang diberikan kepada pesera didik, mereka akan mampu bekerja sama baik dengan kelompoknya maupun dengan kelompok lain. Dengan praktik lapangan ini tentunya pengalaman mereka menjadi bertambah, dan mereka menjadi lebih mandiri, serta mempunyai ide kreatif dan inisiatif untuk mengambil keputusan.

\section{Faktor Pendukung dan Penghambat Pelaksanaan Program Kewirausahaan Bengkel di PKBM Tunas Bangsa Tugu Semarang}

\section{Faktor Pendukung}

Berhasilnya suatu program tentu ada faktor pendukung di dalamnya. Begitu juga dalam program kewirausahaan bengkel di PKBM Tunas Bangsa Tugu. Hal ini didasarkan pada pelatihan yang tidak hanya diorientasikan kepada peserta didik yang sudah bisa tetapi lebih kepada siapa saja yang mau mengikuti pelatihan. Sehingga peserta yang mengikuti pelatihan benarbenar serius dalam mengikuti pelatihan. Motivasi dan kerja sama yang bagus dari peserta didik sangatlah berpengaruh terhadap keberhasilan program. Motivasi yang ditunjukkan oleh peserta didik sangatlah baik.

Sarana-prasaranapun tidak kalah penting untuk menunjang keberhasilan suatu program. Ketersedian sarana-prasarana sangat berpengaruh terhadap proses berjalannya program. Tentu apabila sarana-prasa- 
rana memadai, peserta didik akan lebih menguasai apa yang diajarkan. Sarana-prasarana tentunya tidak lepas dari dari dana. Dana yang diberikan dari pemerintah untuk keberlangsungan program sangatlahlah membantu.

Begitu juga dengan narasumber atau fasilitator yang bagus juga merupakan salah satu pendukung keberlangsungan program. Program kewirausahaan bengkel yang dilaksanakan oleh PKBM Tunas Bangsa Tugu bagi peserta didik mempunyai tujuan untuk mendidik mereka agar mempunyai sikap kewirausahaan untuk bekal hidup mereka. Selain itu diharapkan perilaku dan sikap peserta didik berubah menjadi lebih baik.

Adanya faktor pendukung dalam program kewirausahaan ini tentu mempunyai dampak bagi peserta didik. Ini bisa dilihat dari berubahnya sikap mereka dari sebelum mengikuti program dan setelah maupun sedang mengikuti program kewirausahaan di PKBM Tunas Bangsa Tugu. Peserta didik lebih mandiri, percaya diri, motivasi belajar lebih tinggi, bisa mengontrol emosi, mulai bisa bekerjasama diantara peserta didik, keinginan untuk mencapai tujuan sangat besar, komunikasi belajar dan bekerja menjadi lebih baik dan produktif.

Faktor Penghambat

Penyelenggaraan program tentunya tidak hanya ada pendukungnya, tetapi pasti ada juga penghambat terselenggaranya program tersebut. Beberapa kendalapun dialami dalam penyelenggaraan program kewirausahaan bengkel. Kendala kekosongan narasumber atau fasilitator yang kadang terjadi membuat pesrta didik kesulitan dalam proses belajar. Kendala ini dapat diatasi dengan penambahan narasumber. Oleh karena itu, pihak penyelenggara memberikan tugas ganda bagi para tutor yang bisa untuk merangkap sebagai narasumber pelatihan.

Selain itu tentang alat-alat bengkel yang hilang. Hilang atau berkurangnya alatalat perbengkelan ini tentu saja akan menghambat pekerjaan. Ini terjadi karena kurang hati-hatinya peserta didik maupun pegawai, yang mana setelah memakai alat tidak langsung dikembalikan ketempat semula. Hal ini menyebabkan alat tersebut tidak ke- temu atau hilang. Kelalaian ini bisa diatasi dengan mengingatkan kepada pegawai dan peserta didik untuk lebih hati-hati dan selalu mengembalikan barang ketempat semula setelah memakainya.

\section{PENUTUP}

\section{Simpulan}

Pada konteks penyelenggaraan program kewirausahaan bengkel Paket B Di PKBM Tunas Bangsa Tugu yang meliputi kebutuhan dan partisipasi peserta didik menunjukkan kesesuaian antara program kewirausahaan dengan kebutuhan belajar peserta didik, pengalaman peserta didik yang menunjukkan beberapa dari mereka tidak memiliki dasar dalam keterampilan terutama bengkel.

Penyelenggaraan Program Kewirausahaan Bengkel Paket B di PKBM Tunas Bangsa Tugu Semarang meliputi motivasi peserta didik, pendanaan, dan sarana prasarana dapat disimpulkan baik. Ini terlihat dari motivasi peserta didik yang tinggi, tersedianya sarana-prasarana dan adanya bantuan dana dari pusat.

Pelatihan Program Kewirausahaan Di PKBM Tunas Bangsa Semarang meliputi aktifitas warga belajar, metode pelatihan dan hubungan antar pribadi juga dapat disimpulkan baik. Metode yang digunakan dalam pelatihan kewirausahaan sendiri menggunakan beberapa metode. Di mana metode tersebut disesuaikan dengan kebutuhan saat pelatihan berlangsung. Metode yang digunakan tersebut, yaitu: (1) metode ceramah, (2) metode kelompok (3) metode demonstrasi (4) tutorial, (5) tanya jawab, dan (6) belajar sambil melakukan, dimana masing-masing metode digunakan dalam pemberian teori maupun praktik lapangan disesuaikan dengan kebutuhan peserta didik. Pelaksanaan pembelajaran kewirausahaan bengkel di PKBM Tunas Bangsa Semarang dapat berjalan dengan baik atau dapat terlaksana sesuai dengan tujuan yang direncanakan.

Produk penyelenggaraan Program Kewirausahaan Bengkel di PKBM Tunas Bangsa Tugu Semarang supaya mendapatkan hasil yang baik, teori dan praktik 
lapangan diberikan kepada peserta didik. teori dan praktik yang diberikan kepada peserta didik bisa dikatakan sangat tepat. Hal ini karena disesuaikan dengan kebutuhan peserta.

Faktor pendukung dan penghambat Pelaksanaan Program Kewirausahaan Bengkel di PKBM Tunas Bangsa Tugu. Pendukung dalam terselenggaranya program kewirausahaan ini adalah adanya motivasi yang baik dari peserta didik, selain itu dana dan sarana-prasarana juga sangat mempengaruhi keberlangsungan program. Dengan tersedianya sarana-prasarana yang baik maka proses pelatihan akan berjalan sesuai dengan yang diharapkan.

\section{Saran}

Saran-saran yang dapat disampaikan berdasarkan pada hasil simpulan dan implikasi di atas sebagai berikut: (1) Kinerja narasumber terus ditingkatkan serta penambahan narasumber dengan cara mendatangkan dari instansi terkait; (2) Pengambilan keputusan melibatkan peserta didik; (3) Fasilitator harus memastikan ketersediaan waktunya selama berlangsung-nya program; (4) Menambah fasilitator supaya tidak ada peran ganda di dalam pembelajaran dan pelatihan sehingga hasil akan lebih maksimal.

\section{DAFTAR PUSTAKA}

Hissrich, R.D., \& Peters, M.P (2002). Entrepreneurship. 5th. New York; TheMCGraw Hill.

Kamil, Mustofa. (2009). Pendikan nonformal (pengembangan melalui pusat kegiatan belajar mengajar PKBM di
Indonesia, sebuah pembelajaran dari kominkan Japan). Bandung: Alfabeta

Kementerian Pendidikan dan Kebudayaan. (2013). Petunjuk pelaksanaan bantuan sosial Pendidikan Kewirausahaan Masyarakat (PKM). Jakarta: Direktorat Pembinaan Kursus dan Pelatihan.

Kementerian Pendidikan dan Kebudayaan. (2013). Petunjuk teknis pengajuan, penyaluran, dan pengelolaan bantuan perluasan akses PKBM di kecamatan dan pengembangan PKBM tematik. Jakarta: Direktorat Pembinaan Pendidikan Masyarakat.

Kristanto, H. R. (2009). Kewirausahaan entrepreneurship, pendekatan manajemen dan praktik. Yogyakarta: Graha Ilmu.

Presiden RI. (2010). Peraturan Pemerintah R I Tahun 2010 tentang penyelenggaraan pendidikan serta wajib belajar.

Republik Indonesia. (2003).Undang-undang R.I Nomor 20 Tahun 2003 tentang sisdiknas.

Saleh, Marzuki. (2012). Pendidikan nonformal (dimensi dalam keaksaraan fungsional, pelatihan, dan andragogy) Bandung, Rosda Karya

Stufflebeam. (2003). The CIPP model for evaluation. Portland, Oregon: Western Michigan University.

Suharto, Edi. (2005) Kebijakan sosial (sebagai kebijakan republik), Bandung, Alfabeta 